\title{
Evaluation of distance English language teaching education during COVID-19 pandemic from the perspectives of ELT student teachers and their instructors
}

\author{
Büşra Türegün Çoban ${ }^{1}$ and Aslıhan Kuyumcu Vardar² \\ ${ }^{1}$ Duzce University, Institute of Social Sciences, Turkey (ORCID: 0000-0002-3071-3330) \\ ${ }^{2}$ Duzce University, Faculty of Education, Turkey (ORCID: 0000-0002-0533-7345)
}

\begin{abstract}
Due to the recent COVID-19 pandemic in the world, all institutions of the society have been severely affected. Some of the consequences of this crisis had both positive and negative effects on certain areas. Among these, education is the one that will have the greatest impact on the future. This paper attempted to determine the perspectives of English language teaching student teachers and their instructors on distance education during COVID-19 pandemic. The participants of the study were 40 senior students from the English Language Teaching department and their 4 instructors from a Turkish state university. Both qualitative and quantitative research models were used in this study. Descriptive analysis was used for qualitative data whereas statistical procedure was applied for quantitative data. A questionnaire and semi-structured interview forms were employed as data collection instruments. The results revealed that student teachers and their instructors have both positive and negative opinions about distance English language teaching education during COVID-19 pandemic. One of the most frequently stated problems with distance education refers to student teachers' experiences of teaching practicum, whereas they had no difficulty in theoretical courses. The positive opinions are regarding time-space flexibility, reviewing lessons by recordings, self-paced learning, affordability, comfort, sharing a wide range of resources, instant feedback, whereas negative opinions are about technical problems, applied courses, lack of social interaction, assessment and evaluation, workload, health problems and low motivation. It is suggested that distance education training for both student teachers and instructors will be useful for future experiences.
\end{abstract}

Keywords: Distance education; ELT; Student teachers; COVID-19

Article History: Submitted 29 May 2021; Revised 18 August 2021; Published online 13 September 2021

\section{Introduction}

As practitioners, teachers are the most important component in education systems, because teacher quality matters in achieving goals of education and development of societies. So, in the 21st century, preparing teachers for a changing world is crucial to success in schools and to make contributions to societies (Darling-Hammond, 2006).

Address of Corresponding Author

Aslihan Kuyumcu Vardar, PhD, Düzce University, Faculty of Education, 81620, Düzce, Turkey.

$\triangle$ aslihankuyumcu@duzce.edu.tr

How to cite: Türegün-Çoban, B. \& Kuyumcu-Vardar, A. (2021). Evaluation of distance English language teaching education during COVID-19 pandemic from the perspectives of ELT student teachers and their instructors. Journal of Pedagogical Research, 5(3), 198-220. https:// doi.org/10.33902/JPR.2021371746 
Social facts in the world such as wars, diseases and natural disasters affect all institutions of society. At the forefront of these is education, which shapes the whole society. Spanish Flu or Influenza which was declared as a pandemic in 1918 affected millions likewise. Similarly and recently, the COVID-19 virus, which was first seen in Wuhan, China in 2019, was recognized as a pandemic by the World Health Organization (World Health Organization, 2020). Pandemics can be global and cause deaths in large geographical areas (Aslan, 2020). So, many countries in the world have taken precautions against the COVID-19 pandemic, intervened and continue to do so (Kraemer et al., 2020). The most emphasized three steps against the virus are "masks, social distancing, hand hygiene" (Manikandan, 2020). Schools have been the subject of social distancing. It was reported that more than $91.3 \%$ of students in the world could not go to their schools (UNESCO, 2020), face to face education has been impossible. At this point, the issue of distance education has received considerable critical attention (Telli-Yamamoto \& Altun, 2020). This situation has led countries to transform face to face education into emergency distance education (Bozkurt \& Sharma, 2020). Therefore, there is an urgent need for qualified distance education (Trikoilis \& Papanastasiou, 2020).

\subsection{Distance Education}

Distance education may occur in two ways which are synchronous and asynchronous (Midkiff \& DaSilva, 2011). Data from several studies suggest that there are both advantages and disadvantages of these two types of distance education. The advantages of synchronous distance education are real-time interaction and discussion, instant feedback whereas the advantages of asynchronous distance education are time and space flexibility, supporting learning at an individual pace, being used in non-formal education, and providing lifelong learning opportunities (Fourie, 2001). The disadvantages of synchronous distance education are time management and technical problems while the disadvantages of asynchronous distance education are disconnected student groups, inappropriateness for applied courses, lack of support and feedback (Altıparmak et al., 2011; Midkiff \& DaSilva, 2011; Kırık, 2014; Paydar \& Doğan, 2019). As a result, according to the International Association of Universities' Global Survey Report, time and space flexibility and providing lifelong learning opportunities are stated as advantages of distance education, however, low level of readiness and preparedness, assessment and evaluation, technical infrastructure, inappropriateness for applied courses, and lack of equipment are listed as disadvantages of distance education (Marinoni et al., 2020).

\subsection{Distance Education during COVID-19 around the World}

During the outbreak of COVID-19, distance education has emerged as a common condition all over the world. 429 universities in the world have shifted to distance education (UNESCO, 2020). In China, except for some laboratory courses and applied courses in higher education, distance education was started and the Rain Classroom platform, which has been used in the country since 2016, has been used the most (Lau et al., 2020). Furthermore, when the graduation parties were cancelled in Tokyo, Business Breakthrough University organized a virtual celebration in which students attended by controlling avatar robots (The Guardian, 2020). In the USA, Harvard University (2020) has switched to online education since April, 2020 and is planning a hybrid model for the next year. Massachusetts Institute of Technology (MIT) (2020) and Oxford University (2020) opened offices and laboratories as half of their capacity. Also, Stanford University (2020) held the academic year via distance education. Berkeley University (2020) designed a website called "Caring for Families" in order to support the connection between the parents. In England, there was a shift to distance education after the pandemic. Besides, many universities in England had cancelled the exams (BBC, 2020). Likewise, North Carolina University (2020) changed the alphabetical grading system into a pass-fail system. Plus, it has been announced that the scores students got in distance education will not be included in the cumulative grade point average. Moreover, Educational Testing Service (2020) gave the opportunity of taking central exams at 
home instead of taking them in the exam centers. On the other hand, it is decided to postpone the date of exams in Turkey.

In terms of teaching practicum, Turkey, England and Portugal have switched to online education. Also, Greece and the USA have switched to online peer learning. What is more, Australia has used virtual reality technology for the practicum (Sasaki et al., 2020). Student teachers tried to manage the virtual classroom and student avatars. However, Canada, Malaysia, and Zimbabwe have cancelled the practicum lessons.

\subsection{Distance Education during COVID-19 in Turkey}

The rapid spread of COVID-19 pandemic caused a break for higher education for about three weeks on 13th March, 2020 in Turkey (the Council of Higher Education, 2020). After ten days, there was a call for the universities to start distance education and the Council of Higher Education [CoHE] prepared a database which is full of course materials for online education (CoHE, 2020). According to the data gathered from the CoHE (2020), 121 of the 198 universities in Turkey started distance education after the call, then 41 more after one week and 25 more after two weeks, since many of them had their own online systems beforehand (Telli-Yamamoto \& Altun, 2020). In the spring term of the 2019-2020 academic year, $99.2 \%$ of the universities had their theoretical courses and $89 \%$ of them had theoretical parts of the applied courses via distance education. Google Meet, Google Hangouts, ZOOM, Cisco Webex, Bigbluebutton, Skype, and Microsoft Teams were the most popular platforms used in distance education in Turkish higher education (Telli-Yamamoto \& Altun, 2020). When the main challenge faced by many students was the limited internet quotas, the CoHE signed a protocol with a mobile operator in order to give six GB free internet for the graduate and undergraduate students (CoHE, 2020). There is a growing body of literature that recognises the role of distance education during the COVID-19 pandemic. Several attempts in different countries have been made to demonstrate the role of distance education in higher education during the pandemic (Adnan \& Anwar, 2020; Aristovnik et al., 2020; Edelhauser \& Lupu-Dima, 2020; Elumalai et al., 2021; Gonzalez et al., 2020; Karalis \& Raikou, 2020; Paudel, 2021; Rahiem, 2021).

\subsection{Literature Review}

Recently some researchers have studied the effects of distance education during COVID-19 pandemic on higher education through the views of students in Turkey (Aktaş et al., 2020; Altun et al., 2021; Altun-Ekiz, 2020; Altuntaş-Yılmaz, 2020; Er-Türküresin, 2020; Görgülü-Ar1 \& HayırKanat, 2020; Keskin \& Özer-Kaya , 2020; Ozer \& Ustun, 2020; Sakarya \& Zahal, 2020; Serçemeli \& Kurnaz, 2020; Zan \& Zan, 2020). Previous research comparing face-to-face and online Turkish language lessons in higher education has been conducted by Eroğlu and Kalayc1 (2020). Also, recent work by Sever and Özdemir (2020) has examined the higher education students' views within a photovoice study.

Karadağ and Yücel (2020) determined higher education students' satisfaction levels with distance education whereas Atasoy et al. (2020) determined higher education students' satisfaction levels with e-courses. In addition to these, a study that investigated higher education students' perceptions of stress during distance education conducted by Turan and Gürol (2020).

On the other hand, a number of studies have demonstrated the views of instructors regarding distance education in the pandemic (Almaghaslah \& Alsayari, 2020; Alpaslan, 2020; Altınpulluk, 2021; Sayan, 2020; Serçemeli \& Kurnaz, 2020; Şeren et al., 2020; Yılmaz-İnce et al., 2020b). Next, Korkmaz and Toraman (2020) interviewed teachers who teach from kindergarten to higher education. Also, Özdoğan and Berkant (2020) reported the opinions of all stakeholders about distance education.

However, research to date has not yet determined the views of student teachers and instructors together. This study is set out to investigate the views of both student teachers and their instructors about the distance English language teaching education during COVID-19 pandemic. In addition, most research on evaluation of distance education has been carried out in qualitative 
methods, but data for this study were collected using both qualitative and quantitative methods. In this way, it is expected to reach more valid and reliable findings. Thus, this study aims to contribute to the growing area of distance education in higher education regarding teacher education curricula.

\subsection{The Aim}

The purpose of this research is to examine distance education from the perspectives of English language student teachers and their instructors. Also, answers to following questions are sought.

Regarding the qualitative phase of the study:

- What are the opinions of student teachers and their instructors about the theoretical courses in distance education?

- What are the opinions of student teachers and their instructors about the teaching practicum in distance education?

- What are the top three preferences (likes and dislikes) of student teachers and their instructors regarding distance education?

- What are the suggestions of student teachers and their instructors about distance education?

- Regarding the quantitative phase of the study:

- What are the attitudes of student teachers towards distance education?

- Is there a significant difference between the attitudes scale scores of student teachers in terms of gender?

- Is there a significant difference between student teachers' attitude scale scores according to whether they have distance education experience beforehand or not?

\section{Method}

\subsection{Research Design}

In order to evaluate distance education from the perspectives of both English language student teachers and their instructors, a mixed research method involving qualitative and quantitative data analysis was used in this study. In addition, convergent parallel design is used. This design entails collecting both qualitative and quantitative data at the same time, comparing and relating the two sets of data, and finally interpreting the results. Figure 1 illustrates the research design.

Figure 1

The Convergent Parallel Design of the Study

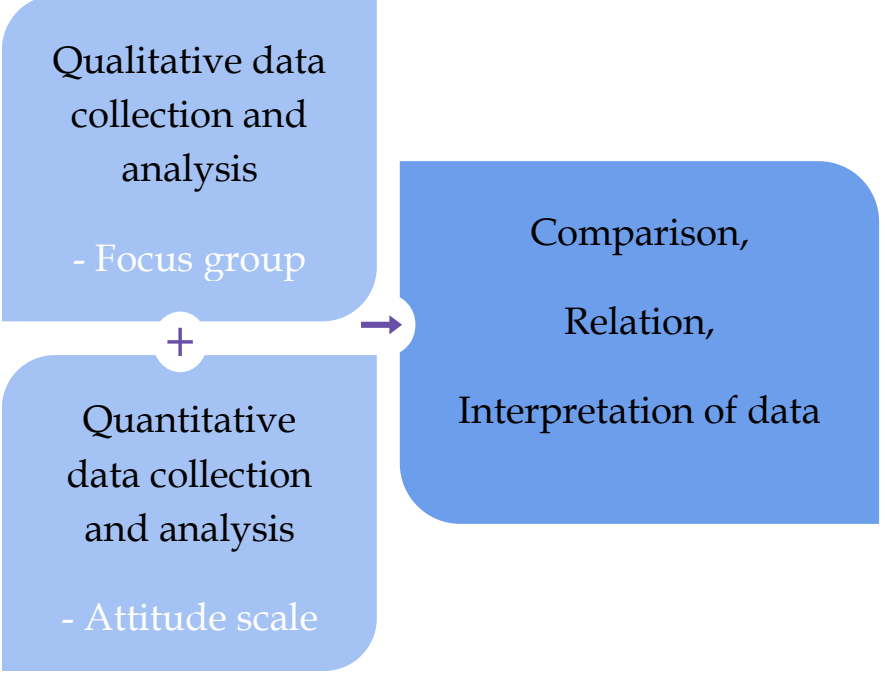

This method and design was used in order to gather more in-depth understanding of the participants' opinions regarding the distance education during COVID-19 pandemic (Creswell \& 
Plano Clark, 2011). Also, semi-structured interview forms and Attitude Scale towards Distance Education were used as data collection tools. For the qualitative phase of the study, focus group interview and individual interviews techniques were used, whereas an attitude scale was used for the quantitative phase of it.

\subsection{Participants}

The participants of this study were 40 senior students (student teachers) in the department of English language teaching at the faculty of education of a state university in the Western Black Sea Region of Turkey in the 2020-2021 academic year, and four instructors who are responsible for their courses. There was a face to face education during the first four weeks of the 2019-2020 academic year (30.09.2019-27.10.2019), and then all the weeks were carried out with distance education. Also, the 2020-2021 academic year was completed with distance education from 05.10.2020 to 28.05.2021. Some characteristics of the participants are presented in Table 1 and Table 2.

Table 1

Characteristics of the Student Teachers

\begin{tabular}{lc}
\hline Characteristics & $f$ \\
\hline Gender & 22 \\
Female & 10 \\
Male & \\
Distance education experience beforehand & 12 \\
Yes & 20 \\
No & \\
\hline
\end{tabular}

According to Table $1,68.75 \%$ of student teachers were female and $31.25 \%$ of them were male. In addition to gender, while $62.5 \%$ of student teachers had never experienced distance education before the COVID-19 pandemic, 37.5\% of them had the common compulsory courses (Atatürk's Principles and History of Turkish Revolution, Turkish Language) through distance education.

Since the participants are 4th grade English language teaching students, in the 2020-2021 academic year, their compulsory theoretical lessons were Atatürk's Principles and History of Turkish Revolution II, Comparative Education, Evaluation and Assessment in Foreign Language Teaching, Turkish Education System, and School Management in distance education. Translation and Socio-linguistics were selective courses. Plus, Teaching Practicum was a compulsory and applied course. Due to the outbreak of COVID-19, the Teaching Practicum course was carried out through live sessions on the ZOOM platform with help of the consultant English language teachers from the Ministry of National Education.

Table 2

Characteristics of the Instructors

\begin{tabular}{|c|c|c|c|c|}
\hline & I1 & $I 2$ & I3 & $I 4$ \\
\hline Gender & Female & Male & Male & Male \\
\hline Seniority & Over 20 years & Over 20 years & Over 20 years & Over 40 years \\
\hline Title & Assist. Prof. Dr. & Lecturer $(\mathrm{PhD})$ & Assist. Prof. Dr. & Assist. Prof. Dr. \\
\hline Profession & $\begin{array}{l}\text { Vocational course } \\
\text { (Educational } \\
\text { Sciences) }\end{array}$ & $\begin{array}{l}\text { Field course } \\
\text { (ELT) }\end{array}$ & Field course (ELT) & Native Speaker \\
\hline Responsibility & $\begin{array}{l}\text { Educational } \\
\text { Sciences } \\
\text { (Theoretical) }\end{array}$ & $\begin{array}{l}\text { Teaching } \\
\text { Practicum } \\
\text { (Practice) }\end{array}$ & $\begin{array}{l}\text { Field course (ELT) } \\
\text { (Theoretical) and } \\
\text { Teaching Practicum } \\
\text { (Practice) }\end{array}$ & $\begin{array}{l}\text { Field course } \\
\text { (ELT) } \\
\text { (Theoretical) }\end{array}$ \\
\hline
\end{tabular}


As seen in Table 2, one of the instructors (I1) is responsible for Educational Sciences, two (I2, I3) for teaching practicum and two (I3, I4) for field courses. The difference between the I3 and I4 is that I4 is a native speaker. Also, the difference between I 2 and I 3 is that I 3 is responsible for both a field course and teaching practicum. Plus, there are some differences between the instructors in terms of gender (I1), seniority (I4) and title (I2). So, these characteristics make the participants valuable for this study.

\subsection{The Development of Data Collection Tools}

During the development of data collection tools, steps presented in Figure 2 were carried out.

Figure 2

Data collection tool development process

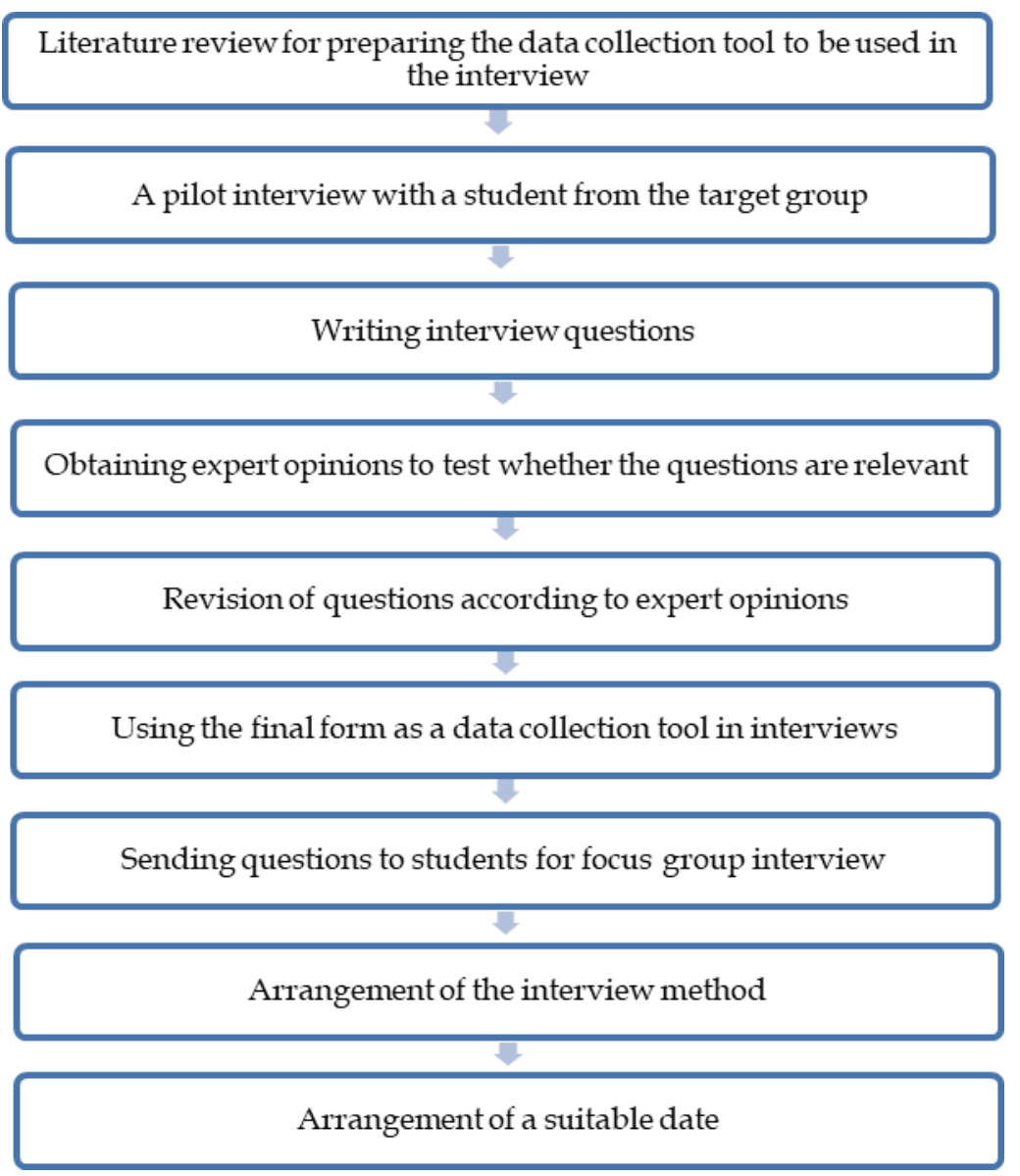

In this study, first of all, related literature was reviewed. A semi-structured interview form developed by the researcher was prepared in order to collect the qualitative data of the research. The focus group interview and individual interviews were conducted by the researcher.

Interview is a technique based on the collection of data through verbal communication (Karasar, 2008). Interviews can be done face-to-face or through devices such as telephone and audio equipment. Due to the outbreak of COVID-19, interviews were conducted online in this study. The feature of semi-structured interview technique is that participants can share their thoughts with details and in depth (Creswell, 2012). The purpose of using the interview technique in this research is to get the opinions of the participants and to extract their in-depth meanings.

Then, a semi-structured interview form was drafted by making use of the studies conducted on distance education in higher education, published articles, internet resources and the opinions of experts in this field. This interview form has four main sections and 34 questions including 'grand tour' questions, core questions and planned and unplanned follow-up questions. These four sections consist of objective, content, learning experiences and evaluation. In the objective part, the 
learning outcomes of the courses are mentioned. In the content part, the content of the courses, the adequacy of the content for distance education and the adequacy of the allocated time are discussed. In the learning experiences part, the questions regarding the methods-techniquesmaterials used in lessons, technology, class participation (active learning), duration of lessons, feedback, preparation, classroom management, ICT literacy, time and space flexibility are included. Finally, the evaluation part is composed of the questions about assignments, take home exams, online exams, validity and reliability. Next, expert opinion was taken in order to ensure the content validity of the interview form. According to the feedback, some questions were shortened, and some were edited in terms of intelligibility. After revising the form by paying attention to the feedback, questions were finalized. After that, in order to test the questions in the interview form, a pilot interview was conducted with an instructor. At the end of this pilot interview, necessary corrections were made to make the questions clear and understandable. So, the semi-structured interview form was ready for the instructors. Also, following the same steps, a semi-structured interview form was prepared for the student teachers after a pilot interview conducted with the student teacher. There are similarities and differences between the questions of interview forms for the student teachers and the instructors. For instance, in terms of the objective part, it was asked to the instructors whether they modify the objectives of the lessons due to the transition of distance education whereas the student teachers were asked whether they reached the objectives of the lessons during the distance education. To illustrate deeply, preparations for online lessons in terms of methods, techniques, materials and plan B were asked to the instructors, and active participation was asked to the student teachers.

The quantitative data of the study were obtained by using the Attitude Scale towards Distance Education developed by Arslan et al. (2019). This scale was chosen in order to reveal the views of 40 senior English language teaching students participating in the study about distance education. However, 32 of them made contributions to the study. This 5-point likert-type scale consists of 21 items and five dimensions. Five dimensions are the advantages of distance education, its technical aspect, the desire for distance education, the effectiveness of teaching in distance education, and the problems of distance education. "Never" as 1, "Rarely" as 2, "Sometimes" as 3, "Usually" as 4, "Always" as 5 points were calculated and negative statements were scored in reverse.

\subsection{Data Collection}

The semi-structured interview form was used for the interviews with four instructors. The interviews lasted approximately 20-30 minutes in person and online. The interviews were carried out with a video conferencing tool named ZOOM. Before the interviews, necessary permissions were taken from the participants to record the interviews. Plus, the researcher took some notes on necessary parts in addition to recording. The other semi-structured interview form was used for one focus group interview with four voluntary student teachers. The focus group interview was conducted via ZOOM and lasted for half past two hours in total. The interview was recorded too with the permissions of student teachers. In order to make the participants feel engaged rather than bored or distracted, there was no order of taking turns in the interview. In order to get deeper answers, their speaking was not interrupted, explanations for their ideas and examples were requested, and additional questions were asked for other details (Şimşek \& Yıldırım, 2013). Although there is no exact number of participants for the focus group interview, there are different opinions in the literature. According to Kitzinger (1995), the number of participants should be between four and nine. It is recommended to be performed with a small number of participants (Çokluk, et al., 2011) because Edmunds (2000) states that when the participants are more than ten people, group interaction may be lost and control may be difficult. According to Krueger (1994), participants' feelings, thoughts, experiences, etc. can be obtained with focus group interview technique. For this reason, this technique was used in order to gather detailed information on the views of student teachers about distance education during COVID-19 pandemic. What's more, the findings of focus group interviews support the findings of individual interviews and surveys 
(Kitzinger, 1995). In order to do so in this study, the Attitude Scale towards Distance Education (Arslan et al., 2019) was used in addition to the focus group interview and individual interviews. The scale was used with 40 senior student teachers and the channel was Google Forms. Apart from the scale's questions, student teachers were asked about their top three likes and dislikes regarding distance education.

\subsection{Validity and Reliability}

In this study, two methods were used to ensure reliability. The first of these is the methods of providing reliability in qualitative research. Within the scope of the methods of providing reliability in qualitative research, the voluntary participants, providing a suitable environment, and the researcher's mastery of the subject and interview technique were taken into consideration. The participants of this study were voluntary to take part in this study. To choose an appropriate environment for the interviews, the online video conferencing program ZOOM was used because of the participants' experiences on this platform and ease of it. The fact that the researcher is an English language teacher, it can be said that the researcher's mastery of the subject is adequate. The literature review on the interview technique and pilot interviews also strengthen the researcher's mastery of the technique. Moreover, coding by different coders for the same data set is a way of increasing reliability in a qualitative method (Baltac1, 2017). What is important in this way is the similarity of two coding processes (Arastaman et al., 2015). This similarity is calculated with MilesHuberman coder reliability percentage (the reliability coefficient $=$ the number of subjects agreed upon/(the number of subjects agreed upon + the number of subjects that were not agreed). It is expected to have at least $80 \%$ similarity among the coders (Miles \& Huberman, 1994). In this study, for these purposes mentioned above, first the student teachers were coded as S1, S2, S3, S4 and instructors as I1, I2, I3, I4 instead of their real names. Then, two researchers worked on the same data set in order to find the coder reliability percentage. It was found that there was $85 \%$ similarity between the coders in this study.

Regarding the quantitative data of the study, the Cronbach Alpha value of the Attitude Scale towards Distance Education (Arslan et al., 2019) was stated as .906 and it was found as .88 in this study. This value means that the scale is suitable for use in terms of reliability and validity. Additionally, necessary permissions were obtained from the authors of the scale before it was used in the study.

\subsection{Data Analysis}

The qualitative data obtained from the interviews were analyzed in accordance with qualitative data analysis methods. For this, the descriptive analysis method was used. In the descriptive analysis technique, the data is interpreted according to predetermined themes. Also, it can be shaped according to different themes obtained during the interviews. The purpose of this technique is to present the data by editing and interpreting (Yıldırım \& Şimşek, 2013). In this research, a framework was formed with the themes obtained from the literature review and interviews. The data processed in accordance with this framework. This data processing was supported by quotations from the interviews and focus group interview, so that the data were defined and the findings were presented. Then, the findings were explained and interpreted (Yildırım \& Şimşek, 2013). Moreover, statistical procedure was implemented to the qualitative data gathered from the attitude scale.

\section{Findings}

In this part of the study, the views of student teachers and their instructors on distance education during the COVID-19 pandemic are presented in tables, classified as themes and sub-themes. Opinions about theoretical courses are given in Table 3, views on teaching practicum in Table 4, the top three likes and dislikes of the participants about distance education in Table 5, and the suggestions of the participants in Table 6 . Then, these tables are illustrated with direct quotations from the participants. Following qualitative data, in accordance with the findings obtained from 
the quantitative data, the participants' level of attitude towards distance education in Table 7, the normality test results according to the gender variable in Table 8 (Shapiro Wilk), the difference in the attitude levels of the participants according to the gender variable in Table 9 (Mann -Whitney $\mathrm{U}$ test), normality test results according to the variable of having pre-distance education experience (Shapiro Wilk) in Table 10, and the difference in attitude levels according to preliminary distance education experience before COVID-19 in Table 11 (Independent samples t-test) are presented. In the tables, there are both student teachers' and the instructors' opinions in order to compare the similarities and differences between the opinions and avoid the unnecessary repetitions.

\subsection{Findings Regarding the Qualitative Phase of the Study}

First, the opinions of student teachers and their instructors about theoretical courses in distance education during COVID-19 are presented in Table 3. In the table, the opinions of the participants are categorized under "insufficient", "acceptable", "sufficient" and "perfect" levels in terms of their satisfaction. This categorization is done according to the participants' opinions. For instance, comments made by the participants like "not enough for me", "doesn't work for me", "I'm unhappy" are regarded as "insufficient", whereas "awesome", "I really like it" are listed under the "perfect" heading.

As I2 stated that "We updated the learning outcomes at the beginning of distance education and shared them with our students" shows the importance of learning outcomes in distance education. According to Table 3, while learning outcomes of theoretical courses in distance education were found sufficient by S1, S2, S3, I1, I2, I3 whereas it was found insufficient by S4 and I4. The main reason for this situation may be that it is easier to reach learning outcomes in theoretical courses in distance education than in applied courses. S1, S2, S3 also verbally stated that they achieved learning outcomes in these lessons. S4 and I4 emphasized that the learning outcomes could not be fully achieved in distance education and that they could only be achieved through face-to-face education. The reason for these views may be that $S 4$ has a dependent learner profile and cannot communicate non-verbally with the instructors in online lessons by saying "I was able to reach the learning outcomes more easily before, my grades were also very high, it does not happen in distance education, I have to be in the classroom again". Also, I4's low level of readiness for distance education may be the reason as I4 said, "It is very difficult to reach all the outcomes in distance education, maybe a few of them are possible for some students".

The content in the theoretical courses was found to be acceptable by I4 and sufficient for distance education by S1, S2, S3, S4, I1, I2, I3. The fact that these courses are "taught verbally by information transfer" (I1) indicates their adequacy for distance education. On the other hand, I4 thinks that this adequacy is at an acceptable level, saying that "not every subject is suitable for distance education". The appropriateness of content for students' levels is important as is its adequacy for distance education. So, the opinions of the participants were taken on this issue too. S1, S2, S3, S4, I4 think that the content is sufficient for the students, while I1, I2, I3 think that it is perfect. The reason why I1, I2 and I3 found the content more appropriate than the other participants may be that these instructors took part in the planning of the content, such as preparing the course description forms. I2 stated that "I know it because I work in the department of the Total Quality Management" and stated that the content was prepared in accordance with the students and that they had a good command of this process. While the intensity of the content in distance education was thought to be sufficient by all student teachers and by I2 and I3, I4 explained that the content was at an acceptable level, with the words "Intensity of the content is higher in face-to-face education" and "intensive, detailed lessons in distance education are difficult". Also, the content's being up to date was found sufficient by all participants. The main reasons for this consensus may be that students can predict the course content since they are senior students, and that the instructors support the content by making "transition to digital resources 





after distance education starts" as I2 said. Lastly, about the time allocated to the content for theoretical courses in distance education was found sufficient by S1, S2, S3, I1, I2, and acceptable level by I3, I4 and I4. "I need more time to internalize the subjects" statement by S4 shows that there are effects of individual differences in learning pace. On the other hand, I3 and I4 added that the sufficiency of allocated time for content depends on the subject matter.

In terms of learning experiences, the first sub-theme is teaching methods. When the participants were asked about the teaching methods used in the theoretical courses in distance education, it was determined that lecture (presentation) method, discussion method, question-answer and seminar techniques were mostly used. Regarding their opinions about these methods, S1 and S4 found these methods insufficient, S2, S3, I4 acceptable, and I1, I2, I3 sufficient. S2 expressed his satisfaction by saying "The presentation method is sufficient because they are effective in theoretical courses", however S1 said that "The presentation method is not enough, it is better even when I study it myself" and that she needs different teaching methods. Also, S4 says "The presentation method is suitable for these courses, but it is suitable in face-to-face education. So, it is not effective in distance education as much as face-to-face education", and this expression shows the difference between distance education and face-to-face education. I1 draws attention to the difficulty of applicability of different teaching methods in distance education by saying "due to the nature of distance education, we use the lecture method". I1, I2 and I3 added that besides the presentation method, they also applied the question-answer and seminar techniques and the discussion method. In addition to these methods, the materials used in distance education theoretical courses were also asked, and it was determined that "video" and some files such as "presentations, slides, lecture notes, articles" were used. While all of the students found these materials insufficient, I4 found them acceptable and I1, I2, and I3 found them sufficient. S1 says "We only used videos in one course", S2 says "Videos were limited, there could be more", and S3 says "Generally, files were shared with us. Different materials could have been used". It is indicated in these comments that files were predominant, but audio-visual materials and digital materials are needed for supporting the theoretical lessons as S4 stated "They can use Web 2.0 tools and other internet sources". I4 supported that the materials were sufficient as an acceptable level with the sentence "the time in distance education is barely enough". Regarding the preparation, I1, I2, I3 stated that this was an increasing workload for them before the learningteaching processes, while S1, S2, S3, S4 and I4 stated that distance education requires an acceptable level of preparation. I4 pointed out that both the student teachers and the instructors make preparations before the lessons in distance education by saying "Students also make some preparations". The comment of "more preparation is required in distance education than in faceto-face education" by I1 and "We have digitized our materials" by I2 show that the workload of the instructors has increased during distance education. About social interaction in distance education, I1, I3, I4 think that it is insufficient, and S1, S2, S3, S4, and I2 think that it is at an acceptable level. Instructors stated that there is much more social interaction in face-to-face education (I4) because they carry out pair or group work (I1), but this is not possible in distance education (I3). Since there was distance education, student teachers were able to communicate with each other via other message applications and could not interact with each other in online courses. I1 added that the platform used in the online lessons allowed the students to communicate in a chat box, but this was at a minimum due to technical problems. All the participants state that an acceptable level of active learning takes place in theoretical lessons during distance education. I2 expressed the limitation of active participation by saying "It turns into a teacher-centered classroom in distance education from student-centered classroom in faceto-face education, even though I always say that they should actively participate". All the participants declared that there is a sufficient level of feedback and communication between students and instructors in distance education for theoretical courses. It supports the fact that students can easily communicate with the instructors (I1) through private messages (I2), WhatsApp (I4), at different times of the day (I3), and similar statements such as "We do not have 
any problems with communicating with the instructors" by the student teachers. However, the participants stated that they had some problems with the physical environment. S4 "Both of us have online lessons in the same room with my brother", S1 "There are some problems in our house" and S2 "We have friends who had these problems, even if we don't have, their situations affect all of us in online lessons", explaining that the physical environment (size of the room, noise, number of people at home) in which student teachers have their online lessons affect the distance education. Furthermore, while S4 had much more internet problems, S1, S2, S3, I4 had fewer problems, and I1, I2, I3 had even fewer internet related problems. The fact that S4 had more and the instructors had less internet problems may be because of the effect of physical and financial opportunities. In terms of hardware (technical devices, accessories) and systematic features (the platform used for distance education), there are no problems in online lessons. The technical problems faced by the participants in the first term of distance education have been solved such as hardware problems stated by S3, S4 and systematic problems stated by I1, I2. However, I3 stated that "The types of the devices student teachers use for distance education also affect the process", and this depends on socio-economic factors.

On the other hand, I4 pointed out that there are student teachers who avoid active participation by pretending that they have these problems. These students make themselves passive listeners rather than active participants in the lessons. At this point, all participants said that information and communication technology (ICT) literacy is an effective factor in distance education. The participants declare that they are capable enough in ICT literacy skills. I1 thinks that the reason for this situation is related to the fact that student teachers are "senior students and their English language proficiency is high". Moreover, in theoretical courses in distance education, all participants found non-verbal communication insufficient whereas time-space flexibility was perfect. S4's sentence "When I don't see my teachers' faces and actions, I can't do it" is an example of the students' need for non-verbal communication, and I4's sentence "I don't know if they understand or not, it is not like face to face, I can't see, so I don't know" is an example of the instructors' need for non-verbal communication. All participants expressed their satisfaction with time-space flexibility. They explained that there are no expenses of transportation (S2, S3, S4), fuel (I4), accommodation (S1), food (S4) in distance education and it happens quickly (S1) and easily (S1) at home (I1, I4).

In theoretical courses during distance education, the validity and reliability of assessment and evaluation were found to be insufficient by S1, S2, S3, S4, I4, and at an acceptable level by I1, I2, I3. I4 expressed this difficulty by saying "Assessment and evaluation in distance education can never be as valid and reliable as face-to-face education", and I1 stated that this is one of the most challenging parts of distance education. Due to the seniority of the participants and the characteristics of the courses they are responsible for, assessment and evaluation in theoretical courses during distance education were carried out with online exams or assignments. Both student teachers and I4 have the opinion that online exams are insufficient, while I1, I2 and I3 think that it is at an acceptable level. I4 states that "I don't know if the students are honest during online exams", pointing out that it is difficult to ensure validity and reliability in online exams. On the other hand, S1 stated that it is difficult to have online exams with the statement "When we experience a systematic problem in an online exam in which we have 20 questions and 25 minutes, it becomes impossible". As an alternative to the online exam, assignments were found to be insufficient by the students due to the workload, and acceptable by the instructors.

In addition, I1, I2, I3 found the theoretical courses sufficient during distance education, S1, S2, S3 found them sufficient at an acceptable level and stated that they were motivated, while S4 and I4 stated that they found the courses inefficient and lost their motivation due to distance education. The reason for this situation can be explained by the fact that S4 has a dependent learner profile since she states "I need to be in the classroom, I need to see the teacher". On the other hand, I4's sentence "It is not possible in distance education" is the expression of his feelings towards distance education and it shows that it affects his motivation negatively. In addition to these, of the 
participants who shared their personal views, S1 stated that some of them experienced eye strain or vision disorders related with focusing on computers for long hours, S2 had vertigo, and S3 had headaches which drew attention to the fact that distance education causes health problems too. On the other hand, S1, S2, S3, I1, I2, I3 believe that distance education will be preferred for theoretical courses in the future, but S4 and I4 do not believe that. Their opinions about the quality of distance education and their motivation towards distance education are factors for their opinions for the future. Finally, all participants agree on receiving supportive training about distance education. They suggest that training on technology integration, ICT literacy, use of Web 2.0 tools, distance education tools and software will be beneficial.

Moreover, in Table 4, the opinions of student teachers and their instructors about teaching practicum (as an applied course) in distance education during COVID-19 are given.

There are similarities as well as some differences between Table 3, which includes the opinions of the participants about the Theoretical courses during distance education and Table 4, which includes the opinions of the participants about the teaching practicum during distance education. Since it is an applied course, participant views differ from theoretical courses in the context of some sub-themes. For instance, S1, S2, S3, S4 stated that they had difficulty in reaching the learning outcomes of the teaching practicum in distance education, while I2 and I3 thought that the students achieved the learning outcomes at an acceptable level. While a student teacher and an instructor think that it is difficult to achieve learning outcomes in theoretical courses, all student teachers think that it is difficult in applied courses. The student teachers stated that the reason for this was that they had never experienced teaching practicum in face-to-face education, this was the first time and through distance education, and therefore it was insufficient for them. Likewise, the adequacy of the content for distance education in the applied course was found to be insufficient by the student teachers and acceptable by the instructors. In the theoretical courses, the content adequacy was found sufficient by the participants. S1 states that "We need to practice, we do it online via ZOOM, there is practice in the online lesson, but we can't see the students". S4 states that "Students do not turn on their cameras, we do not get to know them at all", pointing out that this practice would be incomplete without non-verbal communication. S2 emphasizes the differences in practicum between distance education and face-to-face education by saying "Those who have never been in a real classroom cannot learn classroom management in online lessons". When S1 said, "We have never filled out necessary papers, so we do not know the paperwork", his other friends also agreed with this idea and said that distance education contains much more deficiencies than face-to-face practicum. The fact that I2 stated that "I can't see their clothes, classroom managements or how they react in the classroom" of student teachers in distance education also supports the student teachers' views. I3 stated that "It is not like face to face education, normally we would observe them in their classes" and stated that distance education also limits the methods and techniques in applied courses. Additionally, allocated time to the content to perform the micro-teaching was found to be limited by all the participants. Microteaching and discussion methods were used in this applied course. With the micro-teaching method, pre-service teachers gave lectures in online lessons under the supervision of their advisor teachers (S1, S2, S3, S4). On the other hand, the discussion method was used in order to support these experiences (I2), as well as reading articles on teaching and analyzing it with the questionanswer technique (I3). Student teachers use the lecture (presentation) method in these microteachings. S4 stated that "I would like to use and try different teaching methods, it could be project-based, we could do different activities" and stated that distance education hinders student teachers from applying different teaching methods and techniques. Student teachers' use of materials is at a sufficient level according to all participants. However, they added that they had to use digital materials more than the others and that even digital materials could be used in a limited time. For this reason, preparation for these lessons is seen as a workload by student teachers and they think that it is not worth the preparation compared to face-to-face education. 


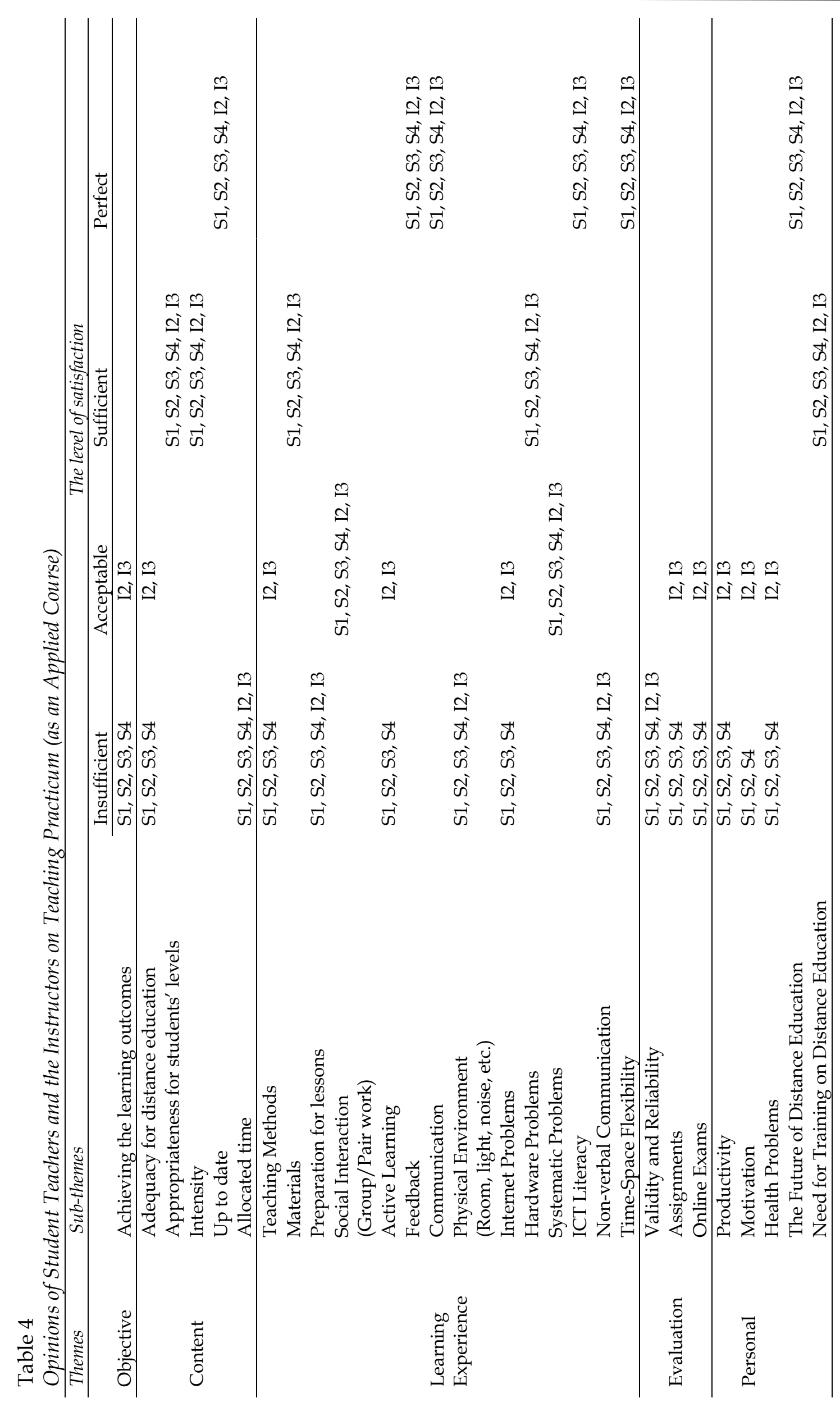


I2 and I3 think that this preparation is at an acceptable level because it provides "preparation for distance education" for student teachers. All participants agreed that social interaction existed at an acceptable level in the practicum. I2 stated "in micro-teaching, student teachers make comments and criticize each other", thus there is more social interaction in practicum than in theoretical courses. The existence of active learning with these micro-teachings was found to be insufficient by the student teachers and acceptable by I2 and I3. It can be said that teacher candidates have high expectations from the practicum, their graduation is close and they do not know how they will act when they enter a real classroom, so they found active learning in practicum during distance education as insufficient. I2 and I3 think that these experiences, even if they are online, are included in active learning under these circumstances. Similar to the theoretical lessons, feedback and communication were found to be perfect by all participants. In addition, the participants evaluated the effects of the physical environment and internet problems negatively which is similar for the theoretical courses. At this time, the problems experienced by student teachers or their students in micro-teaching regarding the ZOOM platform are also included in the systematic problems. Again, similar to the theoretical courses, ICT literacy was evaluated at a sufficient level, non-verbal communication was evaluated at an insufficient level, and time and space flexibility was evaluated at a sufficient level. However, since the assessment and evaluation of the practicum was found to be insufficiently valid and reliable by all participants, this finding is different from the theoretical courses. With the words "We share the rubrics, everyone is ready, but there may be technical problems, so we may not be able to evaluate the micro-teaching", I2 explains that it is very difficult to conduct practicum as an applied lesson in a valid and reliable way during distance education. Within the scope of this course, assessment and evaluation were carried out in the form of reports and online lesson micro-teaching. Reports were found to be insufficient by the student teachers, and it was found to be acceptable by I2 and I3 since online exams could not be done. In order to examine the reasons for these views, efficiency and motivation were questioned as subthemes. Student teachers thought that the practicum in distance education was insufficient and the instructors thought that they were at an acceptable level. In parallel with these views, the motivation of the student teachers is low and the instructors are at an acceptable level. Student teachers said that their motivation was higher in theoretical lessons than practicum. It has been confirmed by all the participants that the supportive training will be beneficial for teaching practicum and other applied courses.

Furthermore, top three likes and dislikes of student teachers and their instructors about distance education during COVID-19 are presented in Table 5. In addition to other data, the top three likes and dislikes were asked to all the student teachers. According to Table 5, the most liked aspects of distance education by student teachers and instructors are that it provides time and space flexibility and reviewing lessons by recording. Sharing a wide variety of resources and using the time more efficiently compared to face-to-face education were the other aspects that were most appreciated by the instructors. Student teachers stated comfort and affordability as other positive aspects. On the other hand, technical problems were the most mentioned negative aspects of distance education. Then, while low participation and the difficulty of assessment and evaluation were found negatively by the instructors, applied courses, lack of social interaction, insufficient teaching methods and techniques were stated as negative aspects by the student teachers. In addition to these, student teachers emphasized the workload (assignments) and health problems caused by distance education. 
Table 5

Top Three Likes and Dislikes of Student Teachers and the Instructors

\begin{tabular}{|c|c|c|c|}
\hline Likes & Participants & Dislikes & Participants \\
\hline Time-space flexibility & $\begin{array}{l}\text { I1, I2, I3, I4, S1, S2, S3, } \\
\text { S4, S7, S24, S25, S26, } \\
\text { S27, S31 }\end{array}$ & Technical problems & $\begin{array}{l}\text { I2, I3, S1, S2, S3, S4, S5, } \\
\text { S7, S8, S9, S10, S11, } \\
\text { S12, S14, S15, S16, S17, } \\
\text { S18, S21, S22, S23, S24, } \\
\text { S25, S26, S27, S20, S28, } \\
\text { S30 }\end{array}$ \\
\hline $\begin{array}{l}\text { Sharing a wide variety } \\
\text { of resources }\end{array}$ & $\mathrm{I} 1, \mathrm{I} 2, \mathrm{I} 3, \mathrm{~S} 18$ & Low participation & $\mathrm{I} 1, \mathrm{I} 2, \mathrm{I} 3, \mathrm{I} 4, \mathrm{~S} 12$ \\
\hline $\begin{array}{l}\text { Effective use of lesson } \\
\text { time }\end{array}$ & $\mathrm{I} 1, \mathrm{I} 3$ & $\begin{array}{l}\text { Difficulty of } \\
\text { assessment and } \\
\text { evaluation }\end{array}$ & $\mathrm{I} 1, \mathrm{I} 2, \mathrm{I} 3, \mathrm{~S} 31$ \\
\hline $\begin{array}{l}\text { Reviewing lessons by } \\
\text { recordings }\end{array}$ & $\begin{array}{l}\text { I2, S1, S2, S3, S4, S5, } \\
\text { S7, S8, S9, S10, S11, } \\
\text { S12, S13, S14, S15, S16, } \\
\text { S17, S18, S20, S21, S22, } \\
\text { S23, S24, S25, S26, S27, } \\
\text { S29, S30, S31, S32 }\end{array}$ & $\begin{array}{l}\text { Lack of social } \\
\text { interaction }\end{array}$ & $\begin{array}{l}\mathrm{I} 1, \mathrm{~S} 3, \mathrm{~S} 4, \mathrm{~S} 9, \mathrm{~S} 12, \mathrm{~S} 14 \\
\mathrm{~S} 16, \mathrm{~S} 22, \mathrm{~S} 23\end{array}$ \\
\hline Affordability & $\begin{array}{l}\text { I4, S1, S2, S3, S4, S17, } \\
\text { S30 }\end{array}$ & Low motivation & I4, S32 \\
\hline Time saving & S7, S9, S11, S14, S23 & Limited time & $\mathrm{I} 4, \mathrm{~S} 14$ \\
\hline $\begin{array}{l}\text { No requirement of } \\
\text { physical preparation }\end{array}$ & S23, S28 & Health problems & $\begin{array}{l}\text { S1, S2, S3, S4, S6, S8, } \\
\text { S11 }\end{array}$ \\
\hline $\begin{array}{l}\text { Protection from } \\
\text { COVID-19 }\end{array}$ & S9, S24, S25, S26, S27 & $\begin{array}{l}\text { Workload } \\
\text { (assignments) }\end{array}$ & S1, S2, S3, S4, S17 \\
\hline Comfort & $\begin{array}{l}\mathrm{S} 6, \mathrm{~S} 8, \mathrm{~S} 10, \mathrm{~S} 11, \mathrm{~S} 13, \\
\mathrm{~S} 15, \mathrm{~S} 16, \mathrm{~S} 17, \mathrm{~S} 19, \mathrm{~S} 21, \\
\text { S22, S28 }\end{array}$ & $\begin{array}{l}\text { Inappropriate physical } \\
\text { environment }\end{array}$ & $\mathrm{S} 7, \mathrm{~S} 8, \mathrm{~S} 28$ \\
\hline \multirow[t]{2}{*}{$\begin{array}{l}\text { No requirement of } \\
\text { attendance }\end{array}$} & S20, S28 & $\begin{array}{l}\text { Insufficient teaching } \\
\text { method and } \\
\text { techniques }\end{array}$ & $\begin{array}{l}\text { S2, S5, S6, S11, S19, } \\
\text { S22, S31 }\end{array}$ \\
\hline & & Applied courses & $\begin{array}{l}\text { S3, S7, S10, S15, S23, } \\
\text { S29 }\end{array}$ \\
\hline
\end{tabular}

Next, the suggestions made by the student teachers and their instructors for distance education are listed in Table 6.

Table 6

Suggestions Made by Student Teachers and Their Instructors for Distance Education

\begin{tabular}{|c|c|}
\hline Suggestions & Made by \\
\hline $\begin{array}{l}\text { Use of teaching methods (such as blended, flipped } \\
\text { learning) }\end{array}$ & $\mathrm{I} 1, \mathrm{I} 2, \mathrm{~S} 1, \mathrm{~S} 2, \mathrm{~S} 3$ \\
\hline Face to face teaching practicum & S1, S2, S3, S4, I2, I3 \\
\hline Use of different methods, techniques, materials & $\mathrm{S} 1, \mathrm{~S} 2, \mathrm{~S} 3, \mathrm{~S} 4$ \\
\hline Supportive training for distance education & S4, I4 \\
\hline Providing hardware support & S4, I4 \\
\hline
\end{tabular}

Student teachers, I2 and I3 stated that the teaching practicum in distance education should be done face-to-face, and the theoretical courses could be done via distance education. Additionally, student teachers emphasized that different methods and techniques should be used in theoretical 
lessons. They shared the idea that "Project-based teaching" and "Problem-based teaching" methods can be used (S1, S4). They added that courses, especially theoretical courses, should be supported with different materials. In this regard, they exemplified the use of Web 2.0 tools (S2, S3). S4 and I4 shared the view that supportive training on distance education would be beneficial. Moreover, while providing hardware support to both student teachers and instructors was recommended by I2 and I4, also providing software support to instructors was added by I4.

\subsection{Findings Regarding the Quantitative Phase of the Study}

In Table 7, the attitude levels of student teachers towards distance education are presented.

Table 7

The Attitude Levels of Student Teachers Towards Distance Education

\begin{tabular}{lccccccc}
\hline & $N$ & $\bar{X}$ & $S D$ & Mode & Median & Min & Max \\
\hline Attitude & 32 & 71.2 & 14.2 & 91.0 & 72.0 & 43 & 91 \\
\hline
\end{tabular}

According to Table 7, student teachers' attitudes towards distance education were found to be moderate $(\bar{X}=71.2)$. In Table 8 , normality of attitude scale scores of student teachers are given.

Table 8

Shapiro Wilk Test Results of Student Teachers' Attitudes Towards Distance Education by Gender

\begin{tabular}{llccc}
\hline & $N$ & $\bar{X}$ & Median & Shapiro-Wilk $(p)$ \\
\hline Female & 22 & 75.7 & 79.5 & .059 \\
\hline Male & 10 & 61.1 & 65.5 & $.039^{*}$ \\
\hline
\end{tabular}

Note. $* p<.05$

According to Table 8, as a result of the Shapiro Wilk test of the attitudes of student teachers towards distance education according to the gender variable, it was determined that while the data showed a normal distribution for female participants, it did not show a normal distribution for male participants. In this case, the Mann-Whitney $U$ test will be used to determine whether there is a significant difference in attitude scores between groups according to gender.

In Table 9, the results of Mann Whitney U test according to gender variable are illustrated.

Table 9

Mann Whitney U Test Results of Student Teachers' Attitude Scores Towards Distance Education by Gender

\begin{tabular}{lcccccc}
\hline & $N$ & Mean Rank & Sum of Ranks & $U$ & $Z$ & $p$ \\
\hline Female & 22 & 19.64 & 432.00 & 41.000 & -2.810 & $.005^{*}$ \\
\hline Male & 10 & 9.60 & 96.00 & & & \\
\hline
\end{tabular}

Note. $* p>.05$

As seen in Table 9, student teachers' attitude scores towards distance education differ according to the gender variable $(U=41.000, p<.05)$. The attitude scores of female student teachers towards distance education are higher than the attitude points of male student teachers towards distance education.

Before the analysis of attitudes scores of student teachers in terms of preliminary experience before COVID-19, the normality test scores are shown in Table 10.

Table 10

Shapiro Wilk Test Results of Student Teachers' Attitudes Towards Distance Education by Preliminary Experience

\begin{tabular}{lcccc}
\hline & $N$ & $\bar{X}$ & Median & Shapiro-Wilk $(p)$ \\
\hline Inexperienced & 20 & 67.5 & 71.0 & .099 \\
\hline Experienced & 12 & 77.3 & 75.0 & .076 \\
\hline
\end{tabular}


According to the Shapiro Wilk test conducted according to preliminary experiences of student teachers, the data are normally distributed. Therefore, the attitude scores of student teachers in terms of preliminary distance education experience before the COVID-19 were analyzed with Independent Sample t-test and given in Table 11.

Table 11

T-test Results of Student Teachers' Attitude Scores Towards Distance Education by Preliminary Experience

\begin{tabular}{|c|c|c|c|c|c|c|}
\hline Groups & $N$ & $\bar{X}$ & $S D$ & $d f$ & $t$ & $p$ \\
\hline Inexperienced & 20 & 67.5 & 14.46 & 30 & -1.963 & .059 \\
\hline Experienced & 12 & 77.3 & 11.99 & & & \\
\hline
\end{tabular}

The attitude scores of student teachers towards distance education do not change according to their experience before distance education $(t(30)=-1.963, p<.05)$. There is no significant difference in the attitudes of student teachers who had or did not have distance education experience before the emergency transition to distance education that started due to the pandemic.

Furthermore, the fact that student teachers' attitude scores towards distance education are at a moderate level coincide with the conclusion that distance education has both positive and negative aspects obtained from qualitative data. The aspects that the student teachers were satisfied with increased the level of attitude, and the aspects that they were not satisfied with decreased the level of attitude, and at the end, it was found that they had a medium level of attitude towards distance education. The fact that female student teachers have a higher level of attitude than male student teachers can be explained by the fact that the number of female student teachers is higher than the number of male student teachers. The fact that the groups did not differentiate according to the feature of having distance education experience before the pandemic may be due to the limited distance education experiences they had before this pandemic. For the first time, during the pandemic, they received a much more comprehensive distance education experience.

\section{Discussion and Conclusion}

In this study, in which the distance English language teaching education during COVID-19 pandemic was evaluated from the perspectives of ELT student teachers and their instructors, it can be concluded that there are both positive and negative aspects of distance education. In line with the opinions of the participants, the most positive aspects of distance education are that it provides time and space flexibility, reviewing lessons by recordings, affordability, comfort, and sharing a wide range of resources, while the prominent negative aspects are technical problems, applied courses, lack of social interaction, insufficient teaching methods and techniques, low participation, assessment and evaluation, workload, health problems and low motivation. Likewise, ErTürküresin (2020) stated that there are both advantages and disadvantages of distance education according to the views of student teachers. The advantages listed as time-space flexibility, reviewing lessons, and affordability and the disadvantages listed as assessment-evaluation problems, hardware and internet problems, lack of interaction are similar to this study.

Similarly, Dilmaç (2020) stated technical problems, loss of motivation and inability to socialize as the negative aspects of distance education. On the other hand, Tümen-Akyıldız (2020) stated that assessment and evaluation and workload are the negative sides of distance education, while the time and space flexibility is the positive side. The technical problems that Dilmaç (2020) mentioned were also highlighted as the negative part of distance education by Yilmaz-İnce et al. (2020a). In this study, technical problems (Dilmaç, 2020; Yılmaz-İnce et al., 2020a) and workload (Tumen-Akyıldız, 2020) were found to be negative aspects. As in the result of Tümen-Akyıldız (2020), it was determined that the time and space flexibility was the most positive aspect. There are also other studies that mentioned time and space flexibility as the dominant positive side (Alpaslan, 2020; Horspool \& Lange, 2012). In addition, Alpaslan (2020) pointed out that the instructors can offer diversity in distance education, and in this study, being able to offer a wide range of resources was noted as another positive side. 
Moreover, similar to this study, Hebebci et al. (2020) also obtained both positive and negative results regarding distance education in their studies. Also, Özdoğan and Berkant (2020) identified positive and negative aspects as in this study. Özdoğan and Berkant's (2020) ranking of the time and space flexibility, reviewing lessons by recordings, and being able to be protected from the virus as advantages are the same as the results of this study. Unlike this study, increased awareness of technology was also explained as an advantage. This difference stems from the fact that the participants of this study are senior English language student teachers, and they have ICT literacy. Özdoğan and Berkant (2020) defined the disadvantages of distance education as lack of assessment and evaluation, motivation, lack of hardware, lack of interaction, technical problems, and inability to socialize. Likewise, in this study, the difficulty of assessment and evaluation, technical problems, low participation, lack of social interaction, and low motivation were expressed by the participants as the negative aspects of distance education. On the other hand, Keskin and Özer-Kaya (2020) stated that students have communication problems besides technical problems. While technical problems are a result of this study, communication problems have not been a negative aspect of distance education. In addition, Kahraman (2020) stated that the Basic Design course which is an applied course in the Faculty of Art and Design was successfully implemented in distance education even though the students had some problems about the materials. Contrariwise, Ozer and Ustun (2020) and Sayan (2020) concluded that distance education is not effective for applied courses as much as face-to-face education. Also, teaching practicum as an applied course is the most stated problem regarding distance education in this study.

Furthermore, in this study, the distance English language teaching education during COVID-19 pandemic was evaluated from the perspectives of ELT student teachers and their instructors. The most common recommendation regarding distance education was face-to-face teaching practicum. Teaching practicum and similar applied courses should be considered within the scope of face-toface education because the opinions about this course in distance education were negative. Therefore, it is possible to mix face-to-face and distance education for senior student teachers. Researchers have introduced a new teaching model called blended learning, which combines the effective aspects of both models (face-to-face and distance learning) (Petronzi \& Petronzi, 2020; Yolcu, 2015). Undoubtedly, efforts in this direction are based on the effort to create a more effective and productive teaching environment. It has been suggested to use different methods, techniques and materials for the theoretical courses in distance education. For this, supportive training on distance education can be provided to student teachers and instructors. With this training, instructors can enrich distance education courses, and student teachers can prepare themselves for distance education in the future. As future teachers, professional development opportunities such as massive open online courses (MOOC) or webinars can be beneficial for them. When necessary, providing hardware and software support to student teachers and instructors were also expressed as suggestions.

For the next normal undergraduate teacher education programs, training on distance education, using hybrid teaching approaches (e.g. blended learning in form of face to face education for practicum, distance education for theoretical lessons), creating a network for supporting ELT student teachers, using different methods and techniques in distance education (such as problem based learning), digitization of documents would be helpful. Also, synchronous and asynchronous distance education can be combined according to the aims and characteristics of the lessons and participants. Paying attention to the workload and health problems may increase the motivation and attitude towards distance education. Regarding teaching practicum in teacher education programs, online teaching strategies should be a part of teaching practicum from now on because of the next normal. For instance, how to increase participation and social interaction in online lessons, teaching integrated four language skills for online, flexibility in teaching, alternative assessment and evaluation, even voice and tone management should be taught in practicum. Also, 
virtual classrooms can be used in order to provide more effective experience for student teachers. It is hoped that these findings and discussion will broaden new horizons for future practice.

Acknowledgement. This paper is the extended version of a contribution to the second International Conference of Pedagogical Research (ICOPR) which was held on May 15-16, 2021 with the hostage of Universiti Utara Malaysia.

\section{References}

Adnan, M., \& Anwar, K. (2020). Online learning amid the COVID-19 pandemic: Students' perspectives. Journal of Pedagogical Sociology and Psychology, 2(1), 45-51. https://doi.org/10.33902/jpsp.2020261309

Aktaş, Ö., Büyüktaş, B., Gülle, M., \& Yıldız, M. (2020). Sports science students' attitudes towards distance education during isolation days caused by Covid-19 virus. Sivas Cumhuriyet University Journal of Sport Sciences, 1(1), 1-9.

Almaghaslah, D., \& Alsayari, A. (2020). The effects of the 2019 novel coronavirus disease (COVID-19) outbreak on academic staff members: A case study of a pharmacy school in Saudi Arabia. Risk Management and Healthcare Policy, 13, 795-802. https://doi.org/10.2147/rmhp.s260918

Alpaslan, M. (2020). Opinions of faculty members on the use of distance education in the education of gifted students. Journal of Open Educational Practices and Researches, 6(1), 126-147.

Altınpulluk, H. (2021). Examination of the views of faculty members in Turkey related to distance education applications in the Covid-19 pandemic process. Gazi University Journal of Gazi Education Faculty, 41(1), 5389.

Altıparmak, M., Kurt, İ. D., \& Kapıdere, M. (2011). E-learning and open source code management systems in education. Paper presented at the XIII. Academic Informatics Conference. Inonu University Department of Computer Education and Instructional Technologies, Malatya.

Altun, T., Akyıldız, S., Gülay, A., \& Özdemir, C. (2021). Investigating education faculty students' views about asynchronous distance education practices during Covid-19 isolation period. Psycho-Educational Research Reviews, 10(1), 34-45.

Altun-Ekiz, M. (2020). The views of physical education and sports school students about distance education in the quarantine period (A qualitative research). Journal of Sport and Recreation Researches, 2(Special issue 1), 1-13.

Altuntaş-Yılmaz, N. (2020). Investigation of students' attitudes towards applied distance education in the Covid-19 pandemic process in higher education institutions: Example of physiotherapy and rehabilitation department. Necmettin Erbakan University Faculty of Health Sciences Journal, 3(1), 15-20.

Arastaman, G., Öztürk-Fidan, İ. \& Fidan, T. (2018). Validity and reliability in qualitative research: A theoretical analysis. Van Yuzuncu Yil University Journal of Education, 15(1), 37-75. https://doi.org/10.23891/efdyyu.2018.61

Aristovnik, A., Keržič, D., Ravšelj, D., Tomaževič, N., \& Umek, L. (2020). Impacts of the COVID-19 pandemic on life of higher education students: A global perspective. Sustainability, 12(20), 8438. https:// doi.org/10.20944/preprints202008.0246.v1

Arslan, R., Bircan, H. \& Eleroğlu, H. (2019). Developing an attitude scale towards lessons in distance education at Cumhuriyet University. Cumhuriyet University Journal of Economics and Administrative Sciences, 20(2), 409-427.

Aslan, H. (2020). A comparative analysis of early social protection measures prepared for Covid-19 pandemic. Journal of Management and Labour, 4(1), 266-291.

Atasoy, R., Özden, C., \& Kara, D. N. (2020). Evaluation of the effectiveness of e-course practices during the Covid-19 pandemic from the students' perspective. Turkish Studies, 15(6), 95-122. https://doi.org/10.7827/turkishstudies.44491

Baltac1, A. (2017). Miles-Huberman Model in qualitative data analysis. Ahi Evran University Institute of Social Sciences Journal, 3(1), 1-14.

BBC. (2020). Coronavirus: More universities halt teaching and exams. Retrieved from https://www.bbc.com/news/education-51880355

Berkeley University (2020). Caring for families. Retrieved from https:/ / family.berkeley.edu/home

Bozkurt, A., \& Sharma, R. C. (2020). Emergency remote teaching in a time of global crisis due to CoronaVirus pandemic. Asian Journal of Distance Education, 15(1), 1-6. 
CoHE (2020). Decisions taken. Retrieved from https:/ / covid19.yok.gov.tr/alinan-kararlar

Creswell, J. W. (2012). Educational research: Planning, conducting, and evaluating quantitative and qualitative research (4th ed.). Pearson.

Creswell, J. W., \& Plano-Clark, V. L. (2011). Designing and conducting mixed methods research (2nd ed.). Sage.

Çokluk, Ö., Yılmaz, K. \& Oğuz, E. (2011). A qualitative interview method: Focus group interview. Journal of Theoretical Educational Science, 4(1), 95-107.

Darling-Hammond, L. (2006). Constructing 21st-century teacher education. Journal of teacher education, 57(3), 300-314. https:// doi.org/10.1177/0022487105285962

Dilmaç, S. (2020). Students' opinions about the distance education to art and design courses in the pandemic process. World Journal of Education, 10(3), 113-126. https:/ / doi.org/10.5430/wje.v10n3p113

Edelhauser, E., \& Lupu-Dima, L. (2020). Is Romania prepared for eLearning during the COVID-19 Pandemic?. Sustainability, 12(13), 5438. https://doi.org/10.3390/su12135438

Edmunds, H. (2000). The focus group research handbook. McGraw-Hill.

Educational Testing Service. (2020). ETS testing updates due to COVID-19. Retrieved from https://www.ets.org/s/cv/important-update/

Elumalai, K. V., Sankar, J. P., Kalaichelvi, R., John, J. A., Menon, N., Alqahtani, M. S. M., \& Abumelha, M. A. (2021). Factors affecting the quality of e-learning during the COVID-19 pandemic from the perspective of higher education students. In C. Cheong, J. Coldwell-Neilson, K. MacCallum, T. Luo \& A. Scime (Eds.), COVID-19 and Education: Learning and Teaching in a Pandemic-Constrained Environment (pp. 167-189). Information Science Press.

Eroğlu, F., \& Kalaycı, N. (2020). Comparative evaluation of the distance and face-to-face education practices in the required Turkish language course at universities. Journal of Mother Tongue Education, 8(3), 10011027. https://doi.org/10.16916/aded.710396

Er-Türküresin, H. (2020). Examination of distance education practices conducted during the Covid-19 pandemic regarding the views of preservice teachers. The Journal of National Education, 49(1), 597-618. https://doi.org/10.37669/milliegitim.787509

Fourie, I. (2001). The use of CAI for distance teaching in the formulation of search strategies. Library Trends, 50(1), 110-129.

Gonzalez, T., De La Rubia, M. A., Hincz, K. P., Comas-Lopez, M., Subirats, L., Fort, S. \& Sacha, G. M. (2020). Influence of COVID-19 confinement on students' performance in higher education. PloS one, 15(10), e0239490. https://doi.org/10.35542/osf.io/9zuac

Görgülü-Arı, A. \& Hayır-Kanat, M. (2020). Prospective teacher' views on Covid-19 (Coronavirus). Van Yuzuncu Yil University The Journal of Social Sciences Institute, (Special Issue on Epidemics), 459-492.

Harvard University. (2020). Harvard University. Retrieved from https:/ / online-learning.harvard.edu/

Hebebci, M. T., Bertiz, Y., \& Alan, S. (2020). Investigation of views of students and teachers on distance education practices during the Coronavirus (COVID-19) Pandemic. International Journal of Technology in Education and Science (IJTES), 4(4), 267-282. https:/ / doi.org/10.46328/ijtes.v4i4.113

Horspool, A. \& Lange, C. (2012). Applying the scholarship of teaching and learning: Student perceptions, behaviours and success online and face-to-face. Assessment \& Evaluation in Higher Education, 37(1), 73-88. https:// doi.org/10.1080/02602938.2010.496532

Kahraman, M. E. (2020). The effect of Covid-19 epidemic on applied courses and the implementation of these courses by distance education: example of basic design course. Journal of Medeniyet Art, 6(1), 44-56. https:// doi.org/10.46641/medeniyetsanat.741737

Karadağ, E., \& Yücel, C. (2020). Distance education at universities during the novel Coronavirus pandemic: An analysis of undergraduate students' perceptions. Journal of Higher Education (Turkey), 10(2), 181-192. https://doi.org/10.2399/yod.20.730688

Karalis, T., \& Raikou, N. (2020). Teaching at the times of COVID-19: Inferences and implications for higher education pedagogy. International Journal of Academic Research in Business and Social Sciences, 10(5), 479-493. https://doi.org/10.6007/ijarbss/v10-i5/7219

Karasar, N. (2008). Bilimsel araştırma yöntemi: Kavramlar, ilkeler, teknikler [Scientific research method: Concepts, principles, techniques]. Nobel.

Keskin, M., \& Özer-Kaya, D. (2020). Evaluation of students' feedbacks on web-based distance education in the COVID-19 process. İzmir Kâtip Çelebi University Faculty of Health Sciences Journal, 5(2), 59-67.

Kırık, A. (2014). Historical development of distance education and the situation in Turkey. Marmara Journal of Communication, 21, 73-94. https:// doi.org/10.17829/midr.20142110299 
Kitzinger, J. (1995). Qualitative research: introducing focus groups. Bmj, 311(7000), 299-302. https:// doi.org/10.1136/bmj.311.7000.299

Korkmaz, G., \& Toraman, Ç. (2020). Are we ready for the post-COVID-19 educational practice? An investigation into what educators think as to online learning. International Journal of Technology in Education and Science (IJTES), 4(4), 293-309. https://doi.org/10.46328/ijtes.v4i4.110

Kraemer M. U. G., Yang, C. H., Gutierrez, B., Wu C. H., Klein B., Pigott, D. M.; Open COVID-19 Data Working Group, du Plessis L., Faria N. R., Li R., Hanage W. P., Brownstein J. S., Layan M., Vespignani A., Tian H., Dye C., Pybus O. G., Scarpino S. V. (2020). The effect of human mobility and control measures on the COVID-19 epidemic in China. Science, 368(6490), 493-497. https:// doi.org/10.1126/science.abb4218

Krueger R. A. (1994). Focus groups: a practical guide for applied research. Sage.

Lau, J., Yang, B., \& Dasgupta, R. (2020). Will the coronavirus make online education go viral? Retrived from https://www.timeshighereducation.com/features/will-coronavirus-make-online-education-go-viral

Manikandan, N. (2020). Are social distancing, hand washing and wearing masks appropriate measures to mitigate transmission of COVID-19?. Vacunas, 21(2), 136. https:// doi.org/10.1016/j.vacun.2020.09.001

Marinoni, G., Van't Land, H., \& Jensen, T. (2020). The impact of Covid-19 on higher education around the world. IAU Global Survey Report.

Midkiff, S. F. \& DaSilva, L. A. (2000, August). Leveraging the web for synchronous versus asynchronous distance learning. Paper presented at the International Conference on Engineering Education, Taipei, Taiwan.

Miles, M. B., \& Huberman, A. M. (1994). Qualitative data analysis: An expanded sourcebook. Sage.

MIT. (2020). Massachusetts Institute of Technology. Retrieved from https://web.mit.edu/

Oxford University. (2020). Oxford and coronavirus. Retrieved from https://www.ox.ac.uk/coronavirus

Özdoğan, A. Ç., \& Berkant, H. G. (2020). The examination of stakeholders' opinions on distance education during the Covid-19 epidemic. Journal of National Education, 49(1), 13-43.

Özer, B., \& Ustun, E. (2020). Evaluation of students' views on the COVID-19 distance education process in music departments of Fine Arts Faculties. Asian Journal of Education and Training, 6(3), 556-568. https:// doi.org/10.20448/journal.522.2020.63.556.568

Paudel, P. (2021). Online education: Benefits, challenges and strategies during and after COVID-19 in higher education. International Journal on Studies in Education, 3(2), 70-85. https://doi.org/10.46328/ijonse.32

Paydar, S., \& Doğan, A. (2019). Teacher candidates' views on open and distance learning environments. Education and Technology, 1(2), 154-162.

Petronzi, R., \& Petronzi, D. (2020). The Online and Campus (OaC) model as a sustainable blended approach to teaching and learning in higher education: A response to COVID-19. Journal of Pedagogical Research, 4(4), 498-507. https://doi.org/10.33902/JPR.2020064475

Rahiem, M. D. H. (2021). Indonesian University students' likes and dislikes about emergency remote learning during the COVID-19 pandemic. Asian Journal of University Education, 17(1), 1-18. https://doi.org/10.24191/ajue.v17i1.11525

Sakarya, G., \& Zahal, O. (2020). The student opinions on distant violin education during Covid-19 epidemic. Electronic Turkish Studies, 15(6). https:// doi.org/10.7827/turkishstudies.44504

Sasaki, R., Goff, W., Dowsett, A., Paroissien, D., Matthies, J., Di Iorio, C., Montey, S., Rowe, S. \& Puddy, G. (2020). The practicum experience during Covid-19 supporting pre-service teachers practicum experience through a simulated classroom. Journal of Technology and Teacher Education, 28(2), 329-339.

Sayan, H. (2020). Assessment of faculty members' views on distance education during the COVID-19 pandemic process. AJIT-e: Online Academic Journal of Information Technology, 11(42), 100-122. https://doi.org/10.5824/ajite.2020.03.004.x

Serçemeli, M., \& Kurnaz, E. (2020). A research on students' perspectives to distance education and distance accounting education in the COVID-19 pandemia period. International Journal of Social Sciences Academic Researches, 4(1), 40-53.

Sever, M. \& Özdemir, S. (2020). The experience of being a student during coronavirus (Covid-19) pandemic: A photovoice study. Journal of Society and Social Work, 31(4), 1653-1679. https://doi.org/10.33417/tsh.778615

Stanford University. (2020). Stanford University. Retrieved from https:/ / online.stanford.edu/

Şeren, N., Tut, E., \& Kesten, A. (2020). Distance education in Corona virus times: Opinions of lecturers'

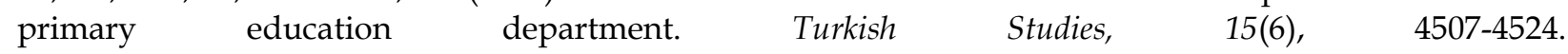
https:// doi.org/10.47423/turkishstudies.46472

Telli-Yamamoto, S. G., \& Altun, D. (2020). The Coronavirus and the rising of online education. Journal of University Research, 3(1), 25-34. https://doi.org/10.32329/uad.711110 
The Guardian (2020, April 8). Robots replace students at Japan graduation ceremony amid Covid-19 outbreak. Retrieved from https://www.theguardian.com/world/video/2020/apr/08/robots-replacestudents-at-japan-graduation-ceremony-amid-covid-19-outbreak-video

Trikoilis, D., \& Papanastasiou, E. C. (2020). The potential of research for professional development in isolated settings during the COVID-19 crisis and beyond. Journal of Technology and Teacher Education, 28(2), 295-300.

Turan, Z. \& Gürol, A. (2020). Emergency transformation in education: Stress perceptions and views of university students taking online course during the COVID-19 pandemic. HAYEF: Journal of Education, $17(2), 222-242$.

Tümen-Aky1ldız, S. (2020). College students' views on the pandemic distance education: A focus group discussion. International Journal of Technology in Education and Science, 4(4), 322-334. https://doi.org/10.46328/ijtes.v4i4.150

North Carolina University. (2020). Response to Global Health Emergency. Retrieved from https://registrar.unc.edu/wp-content/uploads/sites/9/2020/03/emergency-grading-accomodation.pdf

UNESCO. (2020). Education: From disruption to recovery. Retrieved from https://en.unesco.org/covid19/educationresponse

World Health Organization. (2020). World health statistics 2020. Retrieved from https://apps.who.int/iris/bitstream/handle/10665/332070/9789240005105-eng.pdf

Yıldırım, A. \& Şimşek, H. (2013). Sosyal bilimlerde nitel araştırma yöntemleri [Research methods in social sciences]. Seçkin.

Yılmaz-İnce, E., Kabul, A., \& Diler, İ. (2020a). Distance education in higher education in the COVID-19 pandemic process: A case of Isparta Applied Sciences University. Distance Education, 4(4). https://doi.org/10.46328/ijtes.v4i4.112

Yılmaz-İnce, E., Kabul, A., \& Diler, İ. (2020b). The opinions of academicians on distance education During the COVID-19 pandemic. In I. Sahin \& M. Shelley (Eds.), Educational practices during the COVID-19 viral outbreak: International perspectives (pp. 107-120). ISTES Organization.

Yolcu, H. H. (2015). Blended learning and its applications basics. The Journal of Academic Social Science Studies, $33,255-260$.

Zan, N., \& Zan, B. U. (2020). Education in emergency at coronavirus: Overview of faculty of letters students included to distance education system from different regions of Turkey. Electronic Turkish Studies, 15(4), 1367-1394. https:// doi.org/10.7827/turkishstudies.44365 